\title{
PERTUMBUHAN VARIETAS KEDELAI (Glycine max (L.) Merill) PADA GENERASI M2 DENGAN TEKNIK MUTASI
}

\author{
Lilik Harsanti dan Yulidar \\ Pusat Aplikasi Isotop dan Radiasi (PAIR) - BATAN \\ Kawasan Nuklir Pasar Jum'at, Jl. Lebak Bulus Raya No.49, Jakarta - 12440 \\ Email: Lilik-h@batan.go.id \\ Diterima: 07-02-2018 \\ Diterima dalam bentuk revisi: 19-05-2018 \\ Disetujui: 31-01-2019
}

\begin{abstract}
ABSTRAK
PERTUMBUHAN VARIETAS KEDELAI (Glycine max (L.) Merill) PADA GENERASI M2 DENGAN TEKNIK MUTASI. Kedelai merupakan salah satu komoditas nasional handal untuk memenuhi pangan dan industri yang saat ini menjadi tanaman nomor satu untuk tanaman kekacangan. Untuk itu produksi kedelai dalam negeri harus ditingkatkan produksinya, antara lain melalui teknik mutasi radiasi. Telah dilakukan penelitian tanaman kedelai varietas Denna 1 diiradiasi dengan sinar gamma ${ }^{60} \mathrm{Co}$ dosis 0,300 dan 400 Gy (Laju dosis 404,5 Gy/jam). Setelah tanaman mencapai M2 yang ditanam pada musim kemarau pertumbuhan tanaman iradiasi diamati. Kemampuan persentase benih berkecambah umur satu minggu hasil yang tertinggi diperoleh pada dosis 0 Gy sebesar $100 \%$, sedangkan yang terendah pada dosis 400 Gy sebesar $97,78 \%$. Tinggi tanaman pada minggu ke 2 yang tertinggi pada dosis 0 Gy yaitu $19,86 \mathrm{~cm}$, yang terendah pada dosis 400 Gy yaitu $11,28 \mathrm{~cm}$. Kemampuan pertumbuhan tanaman kedelai yang nantinya untuk mendapatkan galur galur mutan kedelai yang terbaik.
\end{abstract}

Kata kunci : iradiasi, dosis, mutasi, kedelai, generasi

\section{ABSTRACT}

GROWTH VARIETY GROWTH (Glycine max (L.) Merill) ON M2 GENERATION WITH MUTATION TECHNIQUES. Soybean is one of important national commodities for food and industry. It is now the number one commodity for legume crops. The national soybean production needs to be increased to fulfill the demand. The research has been conducted using Denna 1 variety irradiated with gamma rays ${ }^{60} \mathrm{Co}$, each with dose of $0 \mathrm{~Gy}, 300 \mathrm{~Gy}$ and $400 \mathrm{~Gy}$ (Dose rate 404,5 Gy/jam). After M1 plants were harvested and M2 seeds were planted and grown into M2 plant in the Field experiment of Ps Jumat PAIR - BATAN. The plants were in the dry season. There are differences in the growth of the plants of different irradiation level. The highest percentage of germinated seeds after one week planting was obtained at 0 Gy (100\%), although not much different from the lowest at 400 Gy $(97,78 \%)$. The plant height at the two weeks after planting was highest at $0 \mathrm{~Gy}(19.86 \mathrm{~cm})$, the lowest is again at $400 \mathrm{~Gy}(11.28 \mathrm{~cm})$. The irradiated plants are capable to grow well in the field, which later might grow into desirable mutant lines.

Key words: irradiation, dosage, mutation, soybean, generation

\section{PENDAHULUAN}

Kedelai merupakan komoditas penting di Indonesia sesudah beras, kebutuhan kedelai di Indonesia setiap tahun selalu meningkat seiring dengan pertambahan penduduk dan perbaikan 
pendapatan perkapita (1). Pengembangan kedelai tanaman disela bawah tegakan tanaman perkebunan, lingkungan agroforestri atau tumpang sari dengan tanaman lain merupakan salah satu alternatif budi daya untuk meningkatkan produksi nasional. Penanaman kedelai sebagai tanaman sela dengan perbedaan tingkat naungan mempengaruhi intensitas cahaya, suhu dan kelembaban udara di lingkungan tanaman, sehingga intensitas cahaya yang diterima tanaman berbeda perbedaan ini mempengaruhi ketersediaan energi cahaya yang akan diubah menjadi energi panas dan energi kimia, untuk mengatasi permasalah diperlukan genotipe kedelai yang toleran terhadap intensitas cahaya rendah (2).

Pemanfaatan lahan dan budidaya tanaman kedelai sebagai tanaman sela di bawah tegakan tanaman perkebunan, hutan tanaman industri $(\mathrm{HTI})$, atau tumpang sari dengan tanaman pangan semusim lain merupakan strategi untuk meningkatkan produksi kedelai nasional. Namun, usaha budidaya kedelai sebagai tanaman sela atau tumpangsari menghadapi berbagai kendala salah satunya kekurangan cahaya akibat naungan (3). Peningkatan produksi kedelai bisa dilakukan dengan 2 cara yaitu dengan perluasan areal tanam dan peningkatan produksi persatuan luas dengan memperbaiki sistim budidaya dan pemakaian varietas unggul. Perakitan varietas unggul baru salah satunya melalui pemuliaan tanaman dengan teknik mutasi radiasi, dengan menggunakan sinar gamma untuk menciptakan keragaman genetik baru (4).
Pemanfaatan sinar gamma sudah berkembang di berbagai bidang untuk kesejahteraan umat manusia, antara lain dibidang kesehatan, industri, pengawetan makanan, pertanian dan lain-lain. Sinar gamma merupakan gelombang elektromagnetik yang mempunyai daya tembus sangat kuat. Salah satu sumber sinar gamma adalah berasal dari ${ }^{60} \mathrm{Co}$, daya tembusnya yang sangat kuat, sinar gamma dapat dimanfaatkan dalam bidang pemuliaan tanaman untuk menciptakan keragaman genetik baru dalam perakitan varietas unggul (1). Pemuliaan tanaman dengan teknik mutasi bertujuan untuk mendapatkan sifat baru dari tanaman melalui perubahan genetik dan sifat dari tanaman induk setelah mendapat radiasi sinar gamma pada dosis tertentu pada tanaman induk (5).

Kelebihan teknik mutasi antara lain adalah salah satu sifat dari suatu varietas dapat diperbaiki tanpa merubah sifat yang lain, menimbulkan sifat baru yang tidak dimiliki oleh induknya, dapat memisahkan pautan gen dan metode ini bersifat komplemen dengan teknik yang lain sehingga teknik tersebut dapat digunakan bersamaan dengan teknik lain seperti hibridisasi dan bioteknologi (6). Pengunaan teknik iradiasi sinar gamma yang tepat dapat meningkatkan frekuensi dan spectrum mutasi (7). Menurunkan efek negative kerusakan fisiologi akibat iradiasi (8). Mutasi adalah suatu proses dimana gen mengalami perubahan atau segala macam tipe perubahan keturunan yang menyebabkan perubahan fenotip yang diwariskan dari satu ke generasi berikutnya (1). 
Pemuliaan tanaman dengan teknik mutasi radiasi sudah berkembang cukup pesat di Indonesia khususnya di Badan Tenaga Nuklir Nasional untuk mendapatkan varietas unggul baru. Saat ini sudah dilepas berbagai varietas unggul padi, kedelai, sorgum, kacang hijau, gandum dan kapas. Berbagai varietas unggul dengan teknik mutasi radiasi tersebut telah ikut berkontribusi dalam peningkatan produksi komoditi pertanian di Indonesia. Salah satu komoditi pertanian yang sudah banyak dihasilkan dengan teknik mutasi radiasi ini adalah kedelai. Saat ini BATAN sudah melepas 10 varietas unggul kedelai melalui pemuliaan tanaman dengan teknik mutasi (8).

Menurut Ashadi (2013) Pemuliaan mutasi untuk perbaikan terhadap umur tanaman menghasilkan sejumlah varietas unggul kedelai berumur genjah dari varietas asalnya. Perlakuan intensitas naungan menunjukkan pengaruh yang nyata terhadap parameter persentase perkecambahan, tinggi tanaman, jumlah cabang, total luas daun, jumlah klorofil, dan jumlah polong berisi. Pendayagunaan sumber daya genetik melalui program pemuliaan untuk mendapatkan varietas kedelai berumur genjah dan produktivitas hasil tinggi, dilakukan dengan berbagai pendekatan, seperti peningkatan keragaman genetik tanaman melalui persilangan, variasi somaklonal, dan teknik mutasi (9).

Mutasi induksi sementara ini merupakan metode pemuliaan yang paling efektif untuk perbaikan satu atau beberapa sifat yang tidak diinginkan. Sejalan dengan ini perbaikan sifat yang diinginkan melalui metode pemuliaan mutasi dapat mungkin berkonsentrasi hanya pada satu target (5). Pemuliaan mutasi di Batan, telah menghasilkan varietas unggul dengan hasil produksi yang tinggi yaitu kedelai berumur genjah (Gamasugen 1 dan Gamasugen 2), Kedelai berbiji besar (Mutiara 1), Kedelai hitam (Mutiara 2 dan 3), kedelai tahan lahan masam (Rajabasa). Mutasi menggunakan iradiasi sinar gamma merupakan salah satu cara untuk meningkatkan keragaman genetik terhadap tanaman kedelai mulai fase awal (perkecambahan), pertumbuhan sampai pada hasil dengan berbagai dosis iradiasi yang nantinya akan menjadi varietas unggul kedelai nasional yang hanya $1 \%$ (1).

Tujuan Penelitian kedelelai tahan naungan dengan menggunakan varietas Denna1 pada generasi M2 merupakan lanjutan tananamn yang dihasilkan tanaman M1 perkebangan selanjutanya untuk mendapatkan galur mutan tanaman kedelai tahan naungan yang genjah, tahan hama penyakit dan produksi tinggi sehingga dapat dinikmati oleh masyarakat luas.

\section{TATA KERJA}

\section{Persiapan Bahan Penelitian}

Rumah naungan dengan memasang bambu untuk rumah naungan atap ditutup dengan jaring, dengan penerimaan intensitas cahaya yaitu $25 \%$ dengan menggunakan alat intensitas cahaya (Lux Meter) yang dapat diterima di rumah naungan, persiapan untuk penanaman benih kedelai tahan naungan di persiapakan 


\section{Penanaman Penelitian}

Bahan yang dipakai adalah benih kedelai varietas Denna1 hasil dari seleksi generasi M1 dengan kadar air di bawah $12 \%$, benih kedelai tahan naungan M2 varietas Denna 1 dengan dosis radiasi 0 Gray, 300 Gray dan 400 Gray, ditanam dirumah naungan satu lubang perbiji kedelai, setelah umur 1 minggu dan 2 minggu dapat diamati.

Jarak tanam 40x15 cm dengan ukuran petak $3 \times 4$ meter. Pemupukan dengan mengunkan dosis standar yaitu $50 \mathrm{~kg}$ urea/ha, $100 \mathrm{~kg} \mathrm{SP} 36 / \mathrm{ha}$ dan $75 \mathrm{kcl} / \mathrm{ha}$. Pengendalian hama dan penyakit dilakukan secara intensif dengan memperhatikan kaidah-kaidah pengendalian hama terpadu.

Pengamatan yang dilakukan meliputi :

1. Kemampuan persentase perkecambah benih kedelai yang dapat hidup.

2. Tinggi Tanaman kedelai berumur 2 minggu.

\section{HASIL DAN PEMBAHASAN}

Tanaman kedelai tahan naungan yang sudah diseleksi pada generasi M.2 yang meliputi tanaman kedelai varietas Denna1 yang dapat tumbuh dengan baik yaitu berumur genjah, penampilan tanaman kokoh dan kuat, tanaman tumbuh sehat dan tahan terhadap serangan hama penyakit. Pada generasi M2 ini dilakukan evaluasi sifat agronomi untuk mendapatkan data-data dan melihat keseragaman atau homogenitas dari tanaman yang terseleksi, terutama tinggi tanaman dan persentasi tanaman yang dapat tumbuh dengan baik pada dosis 300 dan 400 Gray. Pengamatan pada Tabel1. untuk kemampuan prosestase hidup pada varietas denna 1 yang dilapangan dengan prosentase pada dosis 0 gray sangat tumbuh dengan baik $100 \%, 300$ gray tanaman masih dapat tumbuh dengan baik yaitu 99,45\% dan 400 gray masih tumbuh dengan baik yaitu $97,78 \%$, dari pertumbuhan atau kemamapuan hidup yang mana pada masa awalnya masih banyak tanaman yang masih heterozigot masih harus diseleksi menjadi lebih sempurna atau pertumbuhanya yang rata atau homogen. Pemuliaan tanaman dengan teknik mutasi bertujuan untuk mendapatkan sifat baru dari tanaman melalui perubahan genetik dan sifat dari tanaman induk setelah mendapat radiasi sinar gamma pada dosis tertentu pada tanaman induk (8). Juga tampak terlihat pada Gambar 1. semakin tinggi dosis yang diterima akan semakin rendah atau sedikit tanaman yang dapat hidup sempurna.

Table 1. Prosentase (\%) tanaman M2 yang dapat mampu hidup umur 1 minggu setelah tanam pada varietas Denna1

\begin{tabular}{cccccc}
\hline No. & $\begin{array}{c}\text { Dosis } \\
\text { (Gray) }\end{array}$ & I & II & III & X \\
\hline 1 & 0 & 100 & 100 & 100 & 100 \\
2 & 300 & 98,35 & 100 & 100 & 99,45 \\
3 & 400 & 100 & 100 & 100 & 97,78
\end{tabular}

Hal ini mungkin disebabakan oleh pemunculan sifat tersebut di M2 tidak dalam bentuk homozigot dan kemungkinan mutasi terjadi kearah dominan atau semi dominan, atau kemungkinan lain adanya epistatik atau interaksi gen yang tidak aletik lebih besar (9) 


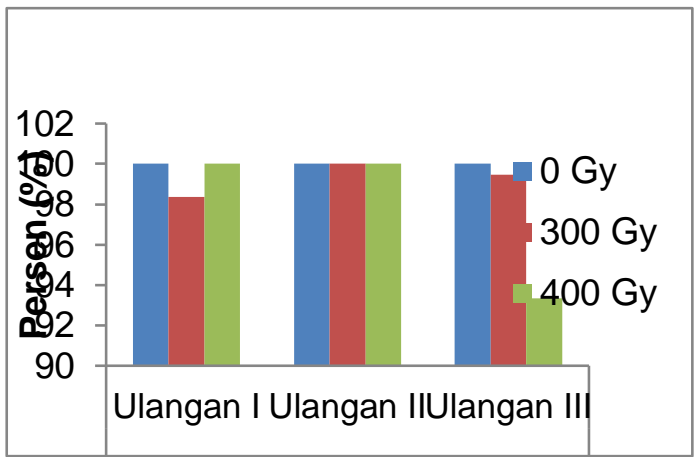

Gambar 1. Kemampuan Prosentase yang Dapat Tumbuh Varietas Denna 1

Intensitas cahaya juga sangat mempengaruhi pertumbuhan cahaya dilapangan atau di rumah naungan terutama pertumbuhan kedelai tahan naungan seperti pada Gambar 1. tanaman kedelai tahan naungan varietas Denna1 yang berumur 2 minggu setelah tanam. Semakin tinggi dosis iradiasi maka akan banyak tanaman yang tidak hidup pada prosentase kematian akan tinggi. Pengaruh rumah naungan sangat dipengaruhi oleh suhu dan kelembapan dari kondisis rumah naungan juga intensitas cahaya yang sampai tidak sampai dibawah kanopi tanaman (2), seperti pada gambar 2. tampak terlihat pertumbuhan dan prosentase tanaman yang dapat tumbuh dengan sempurna atau hidup dengan baik per ulangan I,II dan III. Sinar gamma memproduksi energi, hal ini dapat menyebabkan kerusakan molekul melalui reaksispontan di mana energi radiasi diserap oleh molekul DNA. Pada reaksi tidak langsung energy tidak diserap (diabsorbsi) oleh DNA, tapi oleh molekul lain dalam sel yang memproduksi radikal bebas sehingga mengakibatkan perubahan molekul DNA (6).

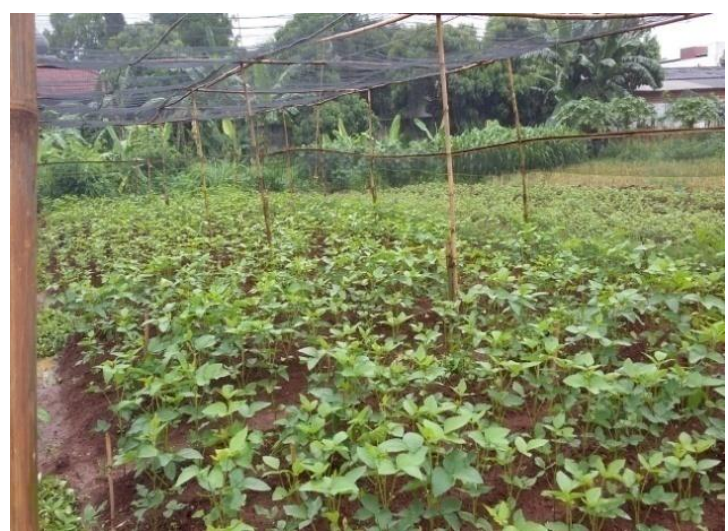

Gambar 2. Tanaman Kedelai Tahan Naungan Varietas Denna 1 Berumur 2 minggu, Ps Jumat.

Pemilihan tanaman kedelai unggul yang nantinya akan mendapatkan bibit unggul yang terbaik baik pemilihan tanaman pergenotipe yang terbaik pada waktu hasil seleksi pergenerasi. Seleksi tanaman dari generasi pergenerasi sangat menentukan tanaman yang diharapkan untuk mendapatkan hasil benih yang unggul (10), dengan cara seleksi yang benar benar yang nantinya untuk mendapatkan varietas unggul kedelai yang dinikmati oleh masyarakat luas khususnya petani (2).

Tinggi tanaman yang berumur 2 minggu tampak terlihat pada Tabel 2. yaitu tinggi tanaman M2 yang dapat mampu hidup umur 2 minggu untuk tanam pada kontrol induknya yaitu varietas Denna1. Ulangan I, II dan III tampak sekali pemilihan orietasi dosis dimulai generasi M1 telah ada perubahan untuk tinggi tanaman hasilnya tidak terlalui pendek sekali, sehingga semakin tinggi dosis radiasi akan semakin rendah tanaman yang pendek yaitu dosis 0 Gray (19.95) sedangkan dosis 400 Gray $(11,28)$ terlihat perubahan tinggi tanaman untuk perdosis rata-ratanya. 
Perbedaannya terlihat sekali efek negatif menyebabakan rerata komponen dari tinggi tanaman hasil pada generasi M2 lebih rendah dari kontrol dan teknik radiasi yang diaplikasikan berpengaruh terhadap kemampuan hidup maupun frekuansi maupun spektrum mutasi (12).

Table 2. Tinggi tanaman M2 yang dapat mampu hidup umur 2 minggu setelah tanam pada varietas Denna1

\begin{tabular}{|c|c|c|c|c|c|c|c|c|c|}
\hline \multirow{2}{*}{$\begin{array}{l}\text { Dosis } \\
\text { (Gy) }\end{array}$} & \multicolumn{9}{|c|}{ Tinggi tanaman $(\mathrm{cm})$} \\
\hline & \multicolumn{3}{|c|}{ Ulangan 1} & \multicolumn{3}{|c|}{ Ulangan 2} & \multicolumn{3}{|c|}{ Ulangan 3} \\
\hline 0 & 19,38 & 19,18 & 19,84 & 20,66 & 20,24 & 20,43 & 19,93 & 19,94 & 19,95 \\
\hline 300 & 12,74 & 13,8 & 11,43 & 12,31 & 12,61 & 13,75 & 12,33 & 15,46 & 14,83 \\
\hline \multirow[t]{6}{*}{400} & 10,89 & 9,32 & 10,53 & 13,8 & 10,66 & 11,43 & 12,98 & 9,43 & 12,48 \\
\hline & & & \multicolumn{3}{|c|}{ Rata-rata $(\mathrm{cm})$} & \multirow{2}{*}{\multicolumn{2}{|c|}{ Rata-rata }} & & \\
\hline & & & U 1 & $\mathrm{U} 2$ & U3 & & & & \\
\hline & & & 19,47 & 20,44 & 19,94 & 19,95 & & & \\
\hline & & & 12,66 & 12,89 & 14,21 & 13,25 & & & \\
\hline & & & 10,25 & 11,96 & 11,63 & $11,2 \varepsilon$ & & & \\
\hline
\end{tabular}

Pertumbuhan tanaman yang terlihat pada ulangan I, II dan III sangat berpengaruh pada beberapa hal bukan hanya unsur hara saja. Pertumbuhan tanaman naungan atau tanaman sela dapat memberikan dampak positif maupun negatif, tergantung tata cara pengelolahannya, penanaman tanaman sela diantaranya contoh pada tanaman Karet melalui ekologi yang tepat dengan mengoptimalkan pemanfaatan cahaya, hara dan air maka kompetisi dan adaptasi akan memberikan tinggi tananamn atau hasil produksi yang diharapkan (2).

Tinggi tanaman sangat berpengaruh pada kemampuan untuk menopang polong tanaman kedelai, semakin tinggi tanaman semakin tanaman tersebut kurang kokoh ini akibat pemilihan atau seleksi dari generasi pergenerasi yang batangnya kokoh atau besar sehingga bisa menopang polongnya banyak tidak mudah roboh maka dibutuhkan tanaman yang batangnya kekar atau kuat untuk menopang tanaman kedelai. Untuk mendapatkan tanaman yang kita inginkan, semakin tinggi dosis iradiasi tanaman kedelai akan semakin tidak mampu untuk bertahan hidup atau mengalami kematian pada setiap perlakuan tanaman (11).

\section{KESIMPULAN}

Kemampuan berkecambah pasca irrdiasi tanaman kedelai tahan naungan yang mampu hidup pada satu minggu setelah tanam yang tertinggi pada dosis 0 Gy yaitu $100 \%$ sedangkan yang terendah pada dosis 400 Gy yaitu 97,78\%. Pada tinggi tanaman pada umur 2 minggu setelah tanam 0 Gy $(19,95 \mathrm{~cm})$ dan yang terendah pada dosis 400 Gy yaitu $11,48 \mathrm{~cm}$. Perlakuan pasca iradiasi orietasi dosis adalah untuk mengetahui dosis pada tanaman, untuk dapat bertahan hidup masing masing tanaman kedelai. 


\section{UCAPAN TERIMAKASIH}

Penulis mengucapkan terima kasih PAIR BATAN untuk anggaran pada tahun 2017. Penulis mengucapkan banyak terima kasih kepada Bapak Suherman, Bapak Parno dan ibu Puput Melati yang telah membantu penelitian dilapangan dimulai penelitian dari penanaman sampai pemanenan, dapat berjalan dengan baik

\section{DAFTAR PUSTAKA}

1. Ashadi. Pemuliaan Mutasi Untuk Perbaikan Terhadap Umur dan Produktivitas pada Kedelai. Jurnal Agrobiogen, 2013;9.(3):135 - 142.

2. Titik $S$ dan Purwantoro. Kesesuaian Genotipe Kedelai untuk Tanaman Sela di Bawah Tegakan Pohon Karet . Jurnal Penelitian Pertanian Tanaman Pangan.2014; 33.(1):44.

3. Gatut W dan Sundari $T$ Perubahan Karakter Agronomi Aksesi Plasma Nutfah Kedelai di Lingkungan Ternaungi. Jurnal Agronomi Indonesia 2011;39(1):16.

4. Karen H, Soybean Oil -Quality Variants Identified by Kanrge -Scale,International Journal of Agronomy 2012; 212:7.

5. Mugiono, Lilik H dan Azri K D. Perbaikan Padi Varietas Cisantana dengan Mutasi Induksi, Jurnal Aplikasi Isotop dan Radiasi 2009;54.(12):194-210.

6. Nunoo,J, Quartey, EK, Amoatey, HM, Klu, G.Y.P., Effect of Recurrent Irradiation on the Improvement of a Variant Line of Wild Tomato (Solanum pimpinellifolium). Journal of Radiation
Research and Applied Sciences. 2014;7:337-383.

7. Human S, Andreani, Sihono and W.M. Indriatama. Stability Test For Sorghum Mutant Lines Derived From Induced Mutations with Gamma-Ray Irradiation. Journal Atom Indonesia 2011;37.(3):102 $-106$.

8. Arwin. Evaluasi Produktivitas Galur-galur Mutan Kedelai Umur Genjah dengan Dua Pola Jarak Tanam pada Lahan Sawah. Prosiding Seminar dan Pameran Teknologi Aplikasi Isotop dan Radiasi, Jakarta. 2013:269 - 277.

9. Anna $P K \mathrm{~K}$, Ying $\mathrm{C}$ UNG, Sobari $\mathrm{H}$, Abdul R H, Atsusi T and Haseyoshihiro, Morpohological and Biochemical Responses of Oryza sativaL (kultival MR 219) to ion beam irradiation, Journal of Zhenjiang University Science 2013;4.(12):53-58.

10. Lilik H. Pengamatan Sifat agronomi, mutu serat dan Hama Penyakit galur Galur Mutan Harapan Kapas (Gosspium hirsutrum L.) Jurnal IImiah Aplikasi Isotop dan radiasi. 2016;12.(2):123-132.

11. Lilik $\mathrm{H}$ dan Yulidar. Pengaruh Iradiasi Sinar Gamma Terhadap Pertumbuhan awal Tanaman Kedelai Glycine Max (L) MERILL) Varietas Denna 2 Prosiding Pertemuan dan Presentasi IImiah Penelitian Dasar IImu Pengetahuan dan Teknologi Nuklir Pusat Sains dan Teknologi Akselerator - BATAN Yogyakarta.2015:59-63.

12. Wijaya Ml, Trikoesoemaningtyas, Syarifah I dan Soeranto H. Pendugaan Ragam Genetik dan Heritabilitas 
Agronomi Gandum (Triticum aestivum L.)

Hasil Berbagi Perlakuan teknik Iradiasi

Gamma. Jurnal Aplikasi Isotop dan

Radiasi.2016;12.(2):79-88. 